\title{
Keynes's General Theory Seventy-Five Years Later
}

\section{Thomas Cate, ed.}

Cheltenham and Northampton, MA: Edward Elgar, 2012, pp. 360 ISBN 978-1-84542-411-4

doi:10.15179/ces.18.1.4

This year will be the eightieth anniversary of the publication of the General Theory. It will also be seventy years since the death of John Maynard Keynes and I am sure that new volumes will appear to add new interpretations or develop ideas derived from the book that radically changed economics and policy making. This year will also mark twenty years since the death of Hyman Minsky, who analyzed the instability of financial markets within a Keynesian framework. The new interest in Keynes and the work of various schools that derive from his work are certainly important in their own right. Nevertheless, I cannot but state that after the "Minsky moment" in 2008 when the financial crisis struck, Keynes was resurrected by the policy makers even if the mainstream academic community had buried him and delegated him to the field of history of economic thought.

The volume under review has contributions by fifteen authors and is divided into four parts covering four topics titled: 1) The GT and Fundamental Uncertainty, 2) The GT and the History of Macroeconomics, 3) The GT and Friedman, Kaldor, Marx and Sraffa and 4) The GT and New Interpretations. 
The position of the editor of this volume is very explicit in the sense that he stresses that Keynes's concept of fundamental uncertainty separates him from the Neoclassical Synthesis (originating with Hicks) and that it implies that business cycles are endogenous and "not exogenous as postulated by real business cycle theory". Secondly, it implies that market economies are prone to liquidity crises. The first paper, by Asensio, takes up on these points and argues that the concept of uncertainty makes it impossible to reach equilibrium without a wider role of institutions that become endogenous forces within the system, but cannot guarantee that the equilibrium solution can be reached. Muchlinski takes this a step further by arguing that the concepts of "vagueness", "state of confidence", uncertainty, conventional judgment, make deductive models based on assumed relationships between variables inappropriate for macroeconomic analysis. The most radical conclusion comes from Hayes, who claims that, contrary to common belief, Keynes's GT has not had a large influence on economics since its insights into the meaning of competitive equilibrium in a monetary economy, the central role and nature of expectations and the meaning of liquidity have been neglected. Hayes goes on to argue that the neglect of these issues has directly affected and limited the scope of measures taken after the financial crisis and that there is a need for a deep reform of the international monetary system along the lines that Keynes was proposing but remained outside the Bretton Woods system.

The second part of the volume starts off with DeVroey's article that shows the evolution of macroeconomics, the paradigm shifts that had occurred with Lucas's critique and the shift to Walrasian approaches, as well as the reactions that led to New Keynesian approaches within the Walrasian approach. Acknowledging that the financial crisis has put the policy issues to the forefront, De Vroey makes a clear distinction concerning the theoretical explanations at the academic level and the economic policy level, basically discarding the call to a return to Keynes. Rather, he argues that such a return is impossible and that the challenges posed to macroeconomics must be addressed by new breakthroughs. To some extent, the article by Dimand is in opposition to that conclusion. He finds that the 
neglect of past achievements and research agendas and problem defining by earlier economists have led to the "reinvention of the wheel". Dimand illustrates his point by analyzing the interwar business cycle and monetary theory. However, his point should be well taken and should be viewed in a broader context, given the low and sometimes practically non-existent attention given to the history of economic thought at the doctoral level. Docherty's article on the quantity theory of money and monetary policy points out the differences between the New Keynesian approaches which include fundamentally monetary and quantitative theory principles as opposed to Post Keynesian approaches. Docherty's exceptional article is important in understanding the potential agenda for Post Keynesian analysis. The article by Luzzetti and Ohanian covers the ground from the peak of Keynesian economics to the triumph of real business cycle models. They do point out that some of the policy prescriptions prevail in some policymaking circles. Ramrattan and Szenberg guide us through the impact of the $G T$ on developing public policies. They conclude that Keynes did not break with the classics and that his $G T$ would generalize the classical theory.

In the third section of the volume, Backhouse and Bateman compare between Friedman's and Keynes's approaches to economics. They find that both used a Marshallian approach to theorizing and used data to inform theorizing. They both used formal models as a framework and were somewhat reserved towards formal theories. Therefore, the authors contend that the major difference between these two giants of economic thought lies in their vision of capitalism, rather than methodology. The article by Camara-Neto and Vernengo brings a long-term view of Keynesian policies. They eloquently argue that Kaldor's introduction of a super-multiplier model of economic growth provides the explanation for variable capacity through interaction with demand-led growth models. In other words, the capacity limit of the economy is endogenous. The late Gilles Dostaler contributes an exquisite piece on the relationship between Keynes and Marx, that is, Keynes's view of Marx, Keynes's changing attitude towards the Soviet Union and the changing attitudes of both Western and Soviet Marxists over the 
years. The article provides insights into the ups and downs of the evaluation of Keynes by Marxist scholars and shows his strong disenchantment with the Soviet Union after Stalin unleashed the terror and collectivization of the 1930s.

The fourth section deals with new interpretations of Keynesianism. Hammond starts off in an article in which he claims that the $G T$ was misread because of the neglect of a serious reading of the Treatise on Money. He builds the case that Keynes's theory is a production- and not demand-driven theory of employment. In other words, inducing investment to create employment and income is at the core of the GT. This is based on expected return that determines new investment. Thus, aggregate demand is what entrepreneurs project that consumer demand would be if they hire a certain level of employment. The next paper by Rochon explores the issue of the existence of endogenous money in Keynes's system. In other words, although Keynes assumed exogenous money supply in the GT, according to Rochon, his analysis is still consistent with endogenous money. In other words, this leads to the conclusion that Keynes's position is close to those held today by Post Keynesians like Lavoie and Moore. This argumentation is backed up by the author's relying on Keynes's later works published after the GT. However, Rochon is careful enough not to go all the way, conceding that Keynes did not give his full attention to the relationship of central banks to commercial banks. Another paper, by Wray, takes up the issue of money supporting the Chartalist approach. Indeed, the author ties Marx, Veblen and Keynes as the theorists of the monetary theory of production. Since money is a public monopoly, created by the state, this has a policy implication meaning that there is no question of affordability in state action in countercyclical policies, just the question of the role of government. Finally, there is an outstanding article by Smithin on the rate of profit and rate of interest in Keynesian, classical and Marxian theories. In an analysis that should be read by advanced students of economic thought, Smithin elegantly describes the systems he analyzes and comes to the conclusion that neoclassical theory, which focuses on an exchange in which there are no profits or they tend to zero, cannot be an adequate theory of 
capitalism. Interest rates can be equalized through the free movement of money, but profit rates cannot, given physical and other obstacles. The analysis of profit rates requires a different approach.

The authors generally reject the Neoclassical Synthesis, the New Classical Economics, as well as the Keynesian approach to macroeconomics. The position taken is mostly Post Keynesian and is openly stated in a fine introduction by Cate. The articles in this volume can be criticized from various angles. Some articles are a digest of work done in previous books. There are some claims that appear exaggerated, for example, the claim by Hayes that the GThad minimal influence. Another example is Hamouda's interpretation of the Treatise on Money which makes that work more important than the GT. It would seem to me that there was a major shift from one to the other. Furthermore, can it not be claimed that the IS-LM approach is Walrasian in nature, and not Marshallian? Can the New Classical Economics be described as Walrasian if it puts the representative agent in the middle with rational expectations and infinite time horizons? Perhaps in some cases things are not as straightforward as the authors claim and would require debate and elaboration.

In spite of other criticisms that can be put forth, this volume is a contribution to the macroeconomic literature that should reach a wider audience. This well written volume by prominent authors should be recommended to all who are interested in what made the $G T$ the most important work in economics in the last eighty years. Perhaps this year, given the eightieth anniversary of its publication, a similar volume will be printed by the publisher.

Ivan Vujačić

Faculty of Economics, University of Belgrade, Serbia 